Troubled Bodies 



\section{Troubled Bodies}

Critical perspectives on postmodernism,

medical ethics, and the body

Edited by Paul A. Komesaroff 
(C) 1995 Duke University Press

All rights reserved

Printed in the United States of America on

acid-free paper $\infty$

Typeset in Minion by Keystone Typesetting, Inc.

Library of Congress Cataloging-in-Publication Data appear on the last printed page of this book. 